\title{
Characteristics of companies with a higher risk of financial statement fraud: a survey of the literature
}

\author{
E du Toit \\ Department of Financial Management \\ University of Pretoria \\ Lynnwood road, Hillcrest, Pretoria, South Africa, 0002 \\ E-mail: elda.dutoit@up.ac.za
}

\begin{abstract}
Fraud and corruption in companies is a serious problem in this day and age. One only needs to think of Enron, Parmalat and Macmed. Companies are constantly identifying new and ingenious ways to defraud their customers, investors, the government and others.
\end{abstract}

For this reason it is important for stakeholders with an interest in a company to devise ways of detecting and identifying fraud to protect their interests. Managers are primarily responsible for the prevention and detection of financial statement fraud. However, they may be the primary perpetrators of fraud. The responsibility to detect and identify financial statement fraud should also not rest solely with the auditors, as they cannot be expected to provide absolute assurance that all material misstatements are detected and identified.

This research set out to find whether there are any characteristics and behavioural aspects in a company by means of which accounting risk and possible financial statement fraud can be detected and identified. Numerous authors gave their insight on the topic in the past, but few came to a clear-cut conclusion of fraud indicators.

The article commences with an explanation of financial statement fraud. It further analyses various authors' statements on the characteristics and behaviours displayed by companies with a higher accounting risk and a propensity for financial statement fraud. The study confirmed that there are behavioural characteristics which can identify the risk of financial statement fraud in 
companies. Parties with an interest in a company, notwithstanding managers and auditors, can observe and measure these characteristics to detect and identify such fraud.

\section{Key words:}

Accounting risk

Auditors

Behaviour
Characteristics

Financial statement fraud

Fraud detection
Fraud identification

Fraud 
In recent years, a number of local companies familiar to the public encountered accounting risk problems and, in some cases, also financial statement fraud problems. Among these companies are Macmed, NAIL, Beige, Masterbond, Saambou, Regal Bank, Unifer, Leisurenet and NRB. Some still survive to this day, but most of them collapsed once the irregularities were discovered.

The parties who have an interest in a company do not only want to see the company prosper in terms of exceptional financial performance and a strong financial position. They also want to see the company display a strong presence in the market and a positive image in the media. For this reason, ethical behaviour is essential. It is, however, difficult for people both in and outside a company to determine whether a company, through its employees and management, displays satisfactory ethical behaviour and does not engage in activities that can increase a company's accounting risk and create the possibility of financial fraud occurring.

The aim of the study was to determine whether there are any means by which parties, internal and external to a company, can establish if a company displays a greater accounting risk and/or perhaps a greater likelihood of the occurrence of financial statement fraud. This was done through a literature analysis of the findings of previous researchers. The article commences with some background on financial statement fraud. Thereafter, an analysis of previous research is presented, followed by the conclusions and areas of further research.

\section{FINANCIAL STATEMENT FRAUD}

\subsection{The occurrence of financial statement fraud}

In 1995, the United States Chamber of Commerce estimated that the annual cost of fraud exceeded $\$ 100$ billion (Glover \& Aono, 1995:3). Two of the largest bankruptcies in America in the 1990s were due to fraud, namely those of Enron and WorldCom (Altman \& Hotchkiss, 2006:3). 
On the domestic front, the South African Police Service (SAPS) reported that South Africa lost R3,4 billion due to commercial crime in the first six months of 1999 (Minnaar-Van Veijeren, 2000c:38). However, according to more recent crime statistics, the incidence of commercial crime is steadily decreasing (South African Police Service, 2005). A total of 55869 cases of commercial crime were reported in 2003/2004, whereas 53931 cases were reported in 2004/2005. However, one must take into account that these figures only reflect reported cases. Even though it may well be that this type of crime is being reduced, it is also possible that fraudsters are becoming smarter and that fraud is not detected, or only reported to a lesser extent.

It is, however, certain that the appearance of financial statement fraud is changing due to greater transparency, faster and more open communication and amounts that appear larger because of inflation (Du Plessis, 2001:4). Other reasons for the change are the globalisation of trade and the use of technology. This provides opportunities for crimes to be committed across borders. The speed and volume of transaction handling have also increased due to changing technology. The Internet and other networks make it easier to gain access to an organisation. Records of liquid assets, such as cash and inventory, are increasingly stored in computer systems as electronic information. It is therefore easier to manipulate records and misappropriate liquid assets.

\subsection{Financial statement fraud defined}

To understand financial statement fraud better, it is useful to look at the various definitions of fraud. The Institute of Internal Auditors (IIA) (2001) defines fraud as "an array of irregularities and illegal acts characterised by intentional deception". Turner (in Elliot \& Willingham, 1980:97) and Robertson (2002:5) define fraud more broadly as "all means that human ingenuity can devise, and which are resorted to by an individual to get an advantage over another by false suggestions or suppression of the truth". This type of fraud includes surprises, tricks, cunning, dissembling and any other unfair way by which another person is cheated.

The definition of financial statement fraud is essentially the same as that of fraud, apart from a few additional aspects. The International Standard of Auditing (ISA) 240 (IAASB, 2007:272) defines corporate fraud as "an intentional act by one or more individuals among management, 
those charged with governance, employees or third parties, involving the use of deception to obtain an unjust or illegal advantage". Financial statement fraud is thus fraud committed by the management of an organisation with the goal to artificially improve the financial performance and results of the company as stated in the financial statements. This is done most often by means of overstating assets and revenue or understating liabilities and expenses.

Financial statement fraud must be clearly distinguished from non-fraudulent earnings management and accounting errors. Non-fraudulent earnings management takes place when a legitimate generally accepted accounting practice (GAAP) method is applied, but only because it has a favourable impact on the financial statements (Rezaee, 2002). An example is a company's management decision to use certain inventory valuation or depreciation methods. Such practices must, however, also be looked upon critically, as it can lead to greater accounting risk in the financial statements of a company. Accounting risk refers to the increased risk of a company's management perpetrating financial statement fraud at some stage in the future to improve the appearance of financial performance and position.

Errors, on the other hand, are unintentional mistakes that appear in financial statements, occurrences that happen without intent. As a result of the lack of intent, errors are normally easier to detect. To make it more difficult to trace, the perpetrator of fraud goes to great lengths to conceal intentional fraudulent misstatements. Sherman, Young and Collingwood $(2003: 6)$ compare fraudulent accounting entries to landmines in the books of a company. These "landmines" are hidden in the books and records of companies and may never "detonate". However, in a case where such an "accounting landmine" is discovered or "detonated", its effects can have a devastating impact on the confidence of investors, creditors, the public and many other related parties. 


\subsection{How and why fraud occurs}

Fraud, especially fraud on behalf of a company, tends to come with a certain organisational culture. It does not mean that a company engaging in fraudulent activities has to have a negative culture. In many cases, it is a positive one where individuals identify strongly with the goals and well-being of a company and want what they believe is best for the company and for themselves. Characteristics associated with fraud include loyalty, cohesiveness, trust, aggressiveness and other attributes mostly valued by companies as traits they prefer in their employees (Elliot \& Willingham, 1980:177). Corporate fraudsters may therefore act with the best intentions and often do not realise that they are acting fraudulently. Robertson (2002) is of the opinion that management behaviour is the main cause behind corporate fraud, as managers are the primary influence in unethical decision-making. They "set the tone at the top" and create what becomes the ethical norm.

Robertson (2002:185) makes use of a fraud triangle (see Figure 1 below) to explain how three basic elements make fraud possible.

\section{Figure 1: The fraud triangle}

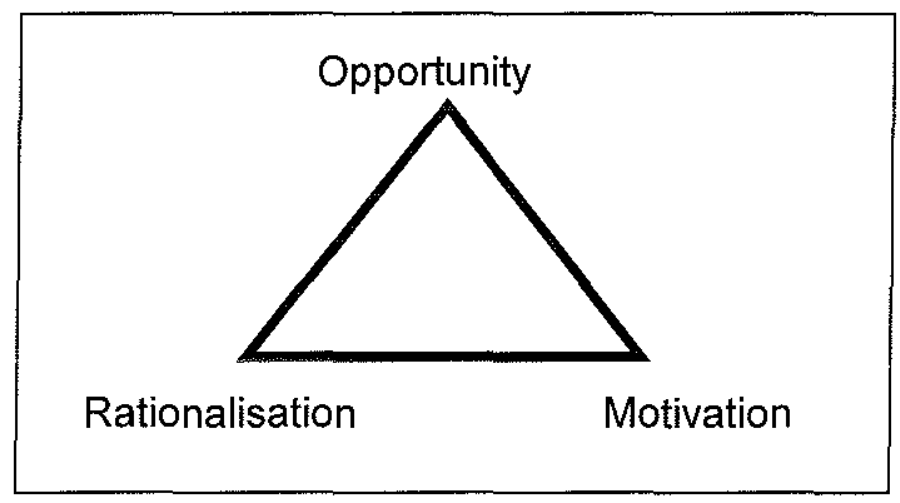

Source: Adapted from Wells (1997:11)

These elements are present in various forms in the characteristics of a firm that engages in fraudulent activities. The elements are as follows (in no particular order):

1. Opportunity is an open door to solve a problem by violating a trust. The higher the position of a person in the organisational hierarchy, the more trust is placed in him/her and the greater his/her opportunity to commit fraud. 
2. Rationalisation (integrity or pressures) is the ability to act according to self-perceived moral and ethical values. Fraudsters find a way to rationalise their actions and make it acceptable for themselves.

3. Motive (incentive) is pressures that a person experiences. These can be "psychotic" (related to habit), egocentric (related to personal prestige), ideological (believing that the cause is morally superior) or economic (related to a need for money).

To get back to the reasons for financial statement fraud specifically, Robertson $(2002: 105)$ has found that financial statement fraud is mostly committed because management tries to make earnings look better. The embezzlement is usually covered up through valuation judgements and manipulating the timing of entries and valuations. Other reasons are encouraging investment, demonstrating higher earnings per share (EPS), dispelling negative market perceptions, obtaining financing, receiving higher acquisition purchase prices, demonstrating compliance with financing covenants and receiving performance-related bonuses. Although financial statement fraud is usually associated with cases where a fraud is perpetrated on behalf of a company, there are cases where managers use their own influence to manipulate company records for their own benefit (Elliot \& Willingham, 1980:8). In such cases, the fraudulent financial statements still harm investors and creditors, because assets that they believe exist, do not really exist.

Sherman, Young and Collingwood (2003:158) state that not only managers, but all investors and other interested parties are to blame for financial statement fraud. They are the ones that keep score of company performance and urge companies to perform better. When it becomes difficult for companies to do better, they have to try and enhance performance through other creative means. The line between what is ethical and what is not, between legality and illegality, is very thin and managers are motivated to operate as closely as possible to that line and to sometimes cross the line. Rezaee $(2002: 183)$ identifies the reasons as perceived benefits that outweigh probable costs, internal and external pressure to show more favourable results, an attitude of "living dangerously" and personal satisfactions. 


\subsection{The effects of financial statement fraud}

Financial statement fraud has larger implications than many managers realise. For many, it is only a means to improve results, but apart from harming the company in which it is being perpetrated, it can also affect economic markets.

Rezaee (2002:7) gives the following summary of the potential harmful effects of financial statement fraud:

- it undermines the quality and integrity of the financial reporting process;

- it jeopardises the integrity and objectivity of the accounting profession;

- it diminishes the confidence of capital markets and market participants in the reliability of financial information;

- it makes the capital market less efficient;

- it adversely affects a nation's growth and prosperity;

- it may result in litigation losses;

- it destroys the careers of individuals involved in the fraud;

- it causes bankruptcy or economic losses by the company engaged in the fraud;

- it encourages a higher level of regulatory intervention; and

- it causes destructions to the normal operations and performance of the alleged companies.

At least for the above reasons, it is necessary to attempt the prevention of fraud incidences. A profile that is developed to analyse a company's character and situation can help interested parties in a proactive way to protect their interests.

\subsection{The detection and identification of financial statement fraud}

In the past there has been a misconception that auditors are responsible for the detection and identification of financial statement fraud. However, auditors' main responsibility is to express an opinion about whether financial statements are prepared within an acceptable accounting framework and thus provide assurance that financial statements are free from material misstatement, whether caused by fraud or error (IAASB, 2007:275). This also relates to the 
definition of an audit as it is set out in the Auditing Profession Act 26 (2005). According to the Act, "audit" means the examination of financial statements in accordance with applicable auditing standards with the objective of expressing an opinion as to their fairness and compliance with a financial reporting framework and any applicable statutory requirements. This implies that auditors should focus on events that have the potential to lead to materially misleading financial statements, but that it is not their sole responsibility to detect and identify such occurrences.

According to ISA 240 (IAASB 2007:274-276), the responsibility of the auditor in the detection and identification of financial statement fraud is limited to retaining an attitude of professional scepticism and considering the possibility of management override of controls. An auditor cannot provide complete assurance that material misstatements will be detected, because of the use of judgment, the use of testing, the inherent limitations of internal control and the fact that much of the audit evidence available to the auditor is persuasive rather than conclusive in nature.

However, if an auditor does come across any material irregularity, Section 45 of the Auditing Profession Act (2005) states that the auditor has a duty to report such material irregularities to the Independent Regulatory Board for Auditors. This duty includes firstly the sending of a written notice to the management of the entity to inform them about the report. Secondly, discussions between the auditors and the management of the entity ensue, in which management are given an opportunity to make representations in respect of the irregularity and a chance to correct the irregularity if they recognise it as a mistake on their part. These discussions and possible changes to the financial statements are to be followed by a second report to the Regulatory Board for Auditors to state whether the situation has changed or stayed the same. For the purpose of the above-mentioned reports, the auditor should get access to any information that may be necessary to carry out additional audit procedures.

ISA 200 (IAASB 2007:222) makes it clear that the management of an entity is responsible for the financial statements of an entity with the oversight of those charged with governance. The audit of financial statements does not relieve management from the responsibility of complying with relevant standards and regulations. For that reason, the responsibility for the detection and identification of financial statement fraud lies ultimately with management and those charged 
with governance and not with the auditor. Managers are in the best position to detect and identify irregularities as a result of having access to all the financial information of the company. Other statements regulating the auditing function and various texts also recognises that all the responsibility for the detection and prevention of financial statement fraud does not rest with the auditor (cf. Robertson, 2002; IAASB, 2007; National Commission on Fraudulent Financial Reporting, 1987; Vaksman, 2004). The problem does arise, however, that managers are in many cases the perpetrators of financial statement fraud and that the fraud will thus not be detected and/or addressed by them.

The fact that auditors cannot be held solely responsible for the detection and identification of financial statement fraud and because managers are often the most likely perpetrators of the fraud, has created an awareness that parties other than auditors and managers should also be responsible for helping authorities with the detection and identification process. It is important for all parties with an interest in a company, not only the managers and auditors, to be aware that financial statements cannot be trusted completely (Glover \& Aono, 1995:8), and to be on the lookout for questionable practices and activities.

Rosplock (2001:24) mentions various statistical and subjective measures that can be used in an investigation. It is particularly important to observe financial information and ratios, using industry and economic data to determine trends, bankruptcy and cash flow risk, information disclosed in notes, the rate of financing and substantial suits, liens or judgments that can have an effect on the company. Most of this information can be found in the financial statements or the notes that accompany the statements.

Glover and Aono (1995:7) point out that a lot can also be learnt from observing additional subjective aspects such as corporate culture, employee turnover, average employee tenure, the nature of customer complaints, product quality, employee morale and employee benefits, the corporate board meeting minutes and other policies and procedures. Information which can be helpful and which is often available in the annual reports is legal battles, credit ratings, investment in employee development, warranty expenses and comparisons of wages with industry averages. Industry trait information is also publicly available and includes industry trade 
journals, business periodicals and newspapers from which new trends can be observed. However, it requires a lot of time and effort to research these, something a private investor or other interested party may not have.

Schilit (1993:19) gives a list of other documents that can be observed to detect and identify financial statement fraud, namely:

- the auditor's report, whether a qualified report was given and/or if an opinion was withheld;

- the proxy statement for pending litigation and executive compensation;

- footnotes for accounting policy changes, related-party transactions and other contingencies or commitments;

- the chairman's letter to determine the forthrightness of management; and

- other quantitative documentation that may give more information on management practices, disputes/disagreements and past performance.

A few articles note that measures to detect fraud, such as the above, are only applicable in certain circumstances (Elliot \& Willingham, 1980:95). This is because there are a multitude of ways in which fraud can be perpetrated and fraudsters are constantly devising new methods. If more methods are used in analysis to detect and identify fraud, the chances of coming across an irregularity are better. It can be detrimental to a study of financial statements if it is too limited. However, it remains possible that the correct mindset can help to detect the presence of fraud.

Financial statement fraud will decline in frequency and severity if more is learnt about it and if that knowledge is used to prevent it (Cressey, 1986:195). Punishing and incapacitating violators of the law would probably help to reduce financial statement fraud, but measures must be implemented to prevent fraud from happening in the first place. No company is immune against the onslaught of fraud and it is becoming the responsibility of everyone - not only managers and auditors - to be aware of fraud and the means to prevent it. 
From the research of various authors, some of which were mentioned in the previous section, it has been found that many researchers agree that the financial statements can be used to detect and identify financial statement fraud occurrences.

This study set out to determine from worldwide research by various authors whether companies with a higher accounting and financial statement fraud risk tend to display specific behavioural characteristics. If this proved to be the case, such characteristics could be integrated into a model of characteristics which auditors, managers and other interested parties can be aware of as potential indicators to assist them in the detection and identification of financial statement fraud.

In order to test whether such behavioural characteristics do exist, research by various authors who wrote about financial statement fraud was sourced from a variety of books and journals. These research studies emanated from around the world, but mostly from the USA. The specific topics or titles of the books and research articles were not considered, only whether the studies made reference to financial statement fraud.

From the work of these authors, categories of behavioural characteristics were identified and analysed. These characteristics include both quantitative and qualitative aspects of business operations. The purpose was to determine each researcher's final conclusion or opinion of a specific behavioural characteristic. The identified characteristics were further analysed to eliminate those of which the authors had opposing views. The end goal was to identify all the characteristics on which previous researchers reached consensus and which they found could be used successfully to identify a company that displays a higher accounting risk and therefore has a greater possibility of financial statement fraud. This will provide interested parties with a range of characteristics that can be applied to evaluate a company's accounting and/or financial statement fraud risk. 


\subsection{Previous research and literature}

Much has been written on the subject of financial statement fraud. Most of the existing literature emanates from the USA. Some authors are Apostolou, Hassell and Webber (2001), Baucus and Near (1991), Beasley (1996), Beasley, Carcello and Hermanson (2001), Beasley, Carcello, Hermanson and Lapides (2000), Bell and Carcello (2000), Beneish (1997), Calderon and Green (1994), Cressey (1986), Dechow, Sloan and Sweeney (1996), DeFond and Jiambalvo (1991), Gerety and Lehn (1997), Kinney and McDaniel (1989), Mitchell (1997), Robertson (2002), Saksena (2001), Summers and Sweeney (1998), Tipgos (2002) and Wells (1990, 1997, 2001). The studies of these authors focus mostly on the theoretical aspects of financial statement fraud and the characteristics of companies that engage in fraudulent activity. Little attention has so far been given exclusively to the detection and identification of fraud in financial statements.

Articles discussing the detection and identification of fraud tend to be geared towards the auditor's responsibility for detecting and identifying fraud, for example, Connelley (2003), Daroca and Holder (1985), Glover and Aono (1995) Heiman-Hoffman, Morgan and Patton (1996), Holder (1983), Hylas and Ashton (1982), Kaminski, Wetzel and Guan (2004), Kinney (1979), Krambia-Kapardis (2002), Lee, Ingram and Howard (1999), Lendez and Korevec (1999), Moyes and Hasan (1996), Nieschwietz, Schultz and Zimbelman (2000) and Persons (1995). These are, therefore, mainly aimed at auditors as the audience.

Thus far there have been little academic writing and research in South Africa on the topic of local financial statement fraud (see Cameron-Ellis, 2000; Christophers, 2005; Dawson, 2001; Du Plessis, 1997, 1999a, 1999b, 2001; Du Plessis \& Koornhof, 2000; Minnaar-Van Veijeren, 2000a, 2000b, 2000c; Savage, 2003; Vaksman, 2004; Van Wyk, 2004). The quality of the available articles is arguably not of the same standard as those from the USA (most of these articles appeared in business magazines and not in accredited scholarly journals). A conference in Johannesburg in 2004 dealt with fraud issues (Padgett, 2004; Perumaul, 2004). Only a few of the 
South African studies mentioned above deal with methods of detecting fraud and identifying its occurrence.

\subsection{The results of various authors' findings}

The 22 most important categories of company characteristics, as identified in an analysis of the works of the above-mentioned authors and other studies, are set out in Table 1. Some of the categories are subjective and others objective. These are arranged in alphabetical order, as the importance of the individual characteristics is not considered in this study.

Table 1: The 22 categories of company characteristics considered in analyses of accounting risk and fraud.

\begin{tabular}{|l|l|}
\hline $\mathbf{N r}$ & Category \\
\hline 1 & Accounting transactions \\
\hline 2 & Auditors \\
\hline 3 & Cash flow \\
\hline 4 & Company age \\
\hline 5 & Company size \\
\hline 6 & Control \\
\hline 7 & Culture \\
\hline 8 & Debt \\
\hline 9 & Directors \\
\hline 10 & Financial distress \\
\hline 11 & Geographic location \\
\hline 12 & Growth \\
\hline 13 & Industry \\
\hline 14 & Liquidity \\
\hline 15 & Management \\
\hline 16 & Personnel \\
\hline 17 & Profitability \\
\hline 18 & Receivables and inventories \\
\hline 19 & Remuneration \\
\hline 20 & Shareholding \\
\hline 21 & Stock market performance \\
\hline 22 & Structure \\
\hline
\end{tabular}

In terms of the 22 categories set out in Table 1, the following table gives the individual contributions of various authors and other sources. Table 2 is a condensation of the specific 
behavioural aspects, according to individual researchers, that one must consider with respect to the 22 identified categories in order to detect and identify financial statement fraud.

Table 2: The findings of the various authors grouped alphabetically according to category.

\begin{tabular}{|c|c|}
\hline \multicolumn{2}{|l|}{ 1. Accounting transactions } \\
\hline $\begin{array}{l}\text { Albrecht, Cherrington, Payne, Roe \& Romney } \\
\text { in Elliot \& Willingham (1980) }\end{array}$ & $\begin{array}{l}\text { Related-party transactions } \\
\text { Large year-end and unusual transactions } \\
\text { Many adjusting entries } \\
\text { Liberal accounting practices }\end{array}$ \\
\hline Apostolou, Hassell \& Webber (2001) & Related party transactions \\
\hline Bell \& Carcello (2000) & $\begin{array}{l}\text { Contentious or difficult transactions } \\
\text { Related-party transactions }\end{array}$ \\
\hline Calderon \& Green (1994) & $\begin{array}{l}\text { Major transactions } \\
\text { Related-party transactions } \\
\text { Transactions difficult to audit }\end{array}$ \\
\hline Plessis (1999b) & Creative accounting \\
\hline Ernst \& Young (2003) & $\begin{array}{l}\text { Unusual transactions affecting earnings } \\
\text { Complex transactions } \\
\text { Related-party transactions }\end{array}$ \\
\hline IAASB (2004) & $\begin{array}{l}\text { Significant related-party transactions } \\
\text { Use of estimates based on subjective judgements } \\
\text { Unusual, significant and complex transactions }\end{array}$ \\
\hline Kinney \& McDaniel (1989) & $\begin{array}{l}\text { Changes to accounting principles } \\
\text { Accounting irregularities }\end{array}$ \\
\hline Lendez \& Korevec (1999) & $\begin{array}{l}\text { Related-party transactions } \\
\text { Complex transactions } \\
\text { Transactions based on subjective estimates }\end{array}$ \\
\hline Mills (2003) & $\begin{array}{l}\text { Accounting practices and transactions that put the company at risk of not } \\
\text { complying to accounting principles }\end{array}$ \\
\hline Mitchell (1997) & $\begin{array}{l}\text { Unusually large transactions, especially at year-end } \\
\text { Many related-party transactions }\end{array}$ \\
\hline $\begin{array}{l}\text { National Commission on Fraudulent Financial } \\
\text { i...porting (1987) }\end{array}$ & $\begin{array}{l}\text { Unusual or complex } \\
\text { Estimates based on subjective judgements } \\
\text { Special valuation needs } \\
\text { Related-party transactions }\end{array}$ \\
\hline Nieschwietz, Schultz Jr \& Zimbelman (2000) & Subjective accounting judgements \\
\hline Price (1991) & Intra-company transactions \\
\hline Rezaee (2002) & $\begin{array}{l}\text { Unusual and/or complex transactions } \\
\text { Unusual and large year-end transactions } \\
\text { Liberal accounting practices } \\
\text { Transactions for which a lot of judgement is needed } \\
\text { Significant related-party transactions } \\
\text { Aggressive attitude towards financial reporting } \\
\end{array}$ \\
\hline Robertson (2002) & $\begin{array}{l}\text { Transactions at odd times } \\
\text { Too many or too few transactions } \\
\text { Too consistent or too different transactions } \\
\text { Difficult accounting measurements }\end{array}$ \\
\hline
\end{tabular}




\begin{tabular}{|c|c|}
\hline & $\begin{array}{l}\text { Difficult-to-audit transactions } \\
\text { Unusual related-party transactions }\end{array}$ \\
\hline Schilit (1993) & $\begin{array}{l}\text { Liberal accounting policies } \\
\text { Unjustified change to accounting policies } \\
\text { Aggressive policies }\end{array}$ \\
\hline \multicolumn{2}{|l|}{ 2. Auditors } \\
\hline $\begin{array}{l}\text { Albrecht, Cherrington, Payne, Roe \& Romney } \\
\text { in Elliot \& Willingham (1980) }\end{array}$ & $\begin{array}{l}\text { Use of different auditing firms or changing auditors often } \\
\text { Reluctance to give data to auditors } \\
\text { Inexperienced auditors }\end{array}$ \\
\hline Apostolou, Hassell \& Webber (2001) & Strained relationship between management and auditors \\
\hline Bell \& Carcello (2000) & $\begin{array}{l}\text { Evasiveness towards auditors } \\
\text { Disputes with auditors } \\
\text { Auditor experience indicating dishonesty } \\
\text { Pressure placed on auditors }\end{array}$ \\
\hline Beneish (1997) & No "big"-firm auditor \\
\hline Calderon \& Green (1994) & $\begin{array}{l}\text { Lies to auditor } \\
\text { Disputes with auditor } \\
\text { Pressure placed on auditors }\end{array}$ \\
\hline Lu Plessis (1999b) & Several firms of auditors \\
\hline Ernst \& Young (2003) & Frequent changes of auditors \\
\hline IAASB (2004) & $\begin{array}{l}\text { Strained relationship with auditor } \\
\text { Frequent disputes with auditors } \\
\text { Unreasonable demands on the auditor (e.g. time to complete audit) } \\
\text { Restrictions on auditor to access people or information }\end{array}$ \\
\hline Kinney \& McDaniel (1989) & Receive more qualified opinions than others in same industry \\
\hline Lee, Ingram \& Howard (1999) & $\begin{array}{l}\text { Changes in auditors } \\
\text { Auditors give more qualified opinions }\end{array}$ \\
\hline Mills (2003) & Same company responsible for internal and external auditing function \\
\hline Mitchell (1997) & Frequent changes to auditors \\
\hline Powell \& Wilkinson (2002) & Concern about auditor visits \\
\hline Rezaee (2002) & $\begin{array}{l}\text { Poor quality external auditors } \\
\text { Lack of due diligence } \\
\text { Frequent changes in external auditors } \\
\text { Restrictions to access people and information } \\
\text { Attempts by management to influence scope of audit }\end{array}$ \\
\hline Robertson (2002) & $\begin{array}{l}\text { Evasiveness to audit enquiries } \\
\text { Disputes with auditors } \\
\text { Opinion shopping }\end{array}$ \\
\hline Schilit (1993) & $\begin{array}{l}\text { Lack of independent/external auditor } \\
\text { Change in auditor or sudden resignation }\end{array}$ \\
\hline Sherman, Young \& Collingwood (2003) & Link between company management and auditor \\
\hline Summers \& Sweeney (1998) & Auditor changes \\
\hline \multicolumn{2}{|l|}{ 3. Cash flow } \\
\hline $\begin{array}{l}\text { Albrecht, Cherrington, Payne, Roe \& Romney } \\
\text { in Elliot \& Willingham (1980) }\end{array}$ & High profit, poor cash flow \\
\hline Apostolou, Hassell \& Webber (2001) & Negative operating cash flow but reported earnings \\
\hline Dechow, Sloan \& Sweeney (1996) & Poor cash from operations to assets ratio \\
\hline Ernst \& Young (2003) & $\begin{array}{l}\text { Profit not consistent with cash flow } \\
\text { Cash pressure in profitable business }\end{array}$ \\
\hline IAASB (2004) & Recurring negative cash flows \\
\hline
\end{tabular}




\begin{tabular}{|c|c|}
\hline & Poor cash flow while reporting earnings and/or earnings growth \\
\hline Lee, Ingram \& Howard (1999) & Low cash flow \\
\hline $\begin{array}{l}\text { National Commission on Fraudulent Financial } \\
\text { Reporting (1987) }\end{array}$ & Inadequate cash flow \\
\hline Powell \& Wilkinson (2002) & Profits not converted into cash \\
\hline Rezaee (2002) & $\begin{array}{l}\text { Insufficient cash to support reported earnings growth } \\
\text { Cash shortage or negative cash flow }\end{array}$ \\
\hline Sherman, Young \& Collingwood (2003) & Cash receipts from customers not in line with sales figures \\
\hline \multicolumn{2}{|l|}{ 4. Company age } \\
\hline Beneish (1997) & Younger firms \\
\hline Fridson \& Alvarez (2002) & Younger companies \\
\hline Lee, Ingram \& Howard (1999) & Younger firms \\
\hline Schilit (1993) & Recently became public company \\
\hline Sherman, Young \& Collingwood (2003) & Younger companies often have unconventional methods \\
\hline \multicolumn{2}{|l|}{ 5. Company size } \\
\hline Baucus \& Near (1991) & Large firms \\
\hline $\begin{array}{l}\text { Beasley (1996), } \\
\text { isley, Carcello \& Hermanson (2001), } \\
\text { Beasley, Carcello, Hermanson \& Lapides } \\
(2000)\end{array}$ & Small to mid-size companies \\
\hline Cressey (1986) & Firms in smaller towns violate the law more \\
\hline Davia, Coggins, Wideman, Kastantin (2000) & Smaller companies are the largest fraudsters \\
\hline DeFond \& Jiambalvo (1991) & Smaller companies \\
\hline Fridson \& Alvarez (2002) & Small and large companies \\
\hline Hylas and Ashton (1982) & $\begin{array}{l}\text { Errors in revenue cycle, property, plant and equipment, prepaid } \\
\text { expenses, deferred charges and other assets occur more in smaller } \\
\text { companies while errors in inventory, notes receivable and other } \\
\text { liabilities tend to occur more in larger companies }\end{array}$ \\
\hline Kinney \& McDaniel (1989) & Smaller firms \\
\hline Persons (1995) & Smaller firms \\
\hline Rezaee (2002) & Large and decentralised \\
\hline Saksena (2001) & Larger firms \\
\hline \multicolumn{2}{|l|}{ 6. Control } \\
\hline $\begin{array}{l}\text { Albrecht, Cherrington, Payne, Roe \& Romney } \\
\text { in Elliot \& Willingham (1980) }\end{array}$ & Poor internal control \\
\hline r. ostolou, Hassell \& Webber (2001) & Poor attitude towards internal control \\
\hline Bell \& Carcello $(2000)$ & Weak internal control \\
\hline Calderon \& Green (1994) & Weak internal control \\
\hline Davia, Coggins, Wideman, Kastantin (2000) & No adaptation of controls to changes \\
\hline Dechow, Sloan \& Sweeney (1996) & Weak overview of affairs by management \\
\hline DeFond \& Jiambalvo (1991) & Weak internal controls \\
\hline Du Plessis (1999b) & $\begin{array}{l}\text { Poor commitment to control } \\
\text { Poor strategy formulation }\end{array}$ \\
\hline Ernst \& Young (2003) & $\begin{array}{l}\text { Lack of response to management queries } \\
\text { Management overrides controls } \\
\text { Rumours and tip-offs that controls are not adhered to } \\
\text { Unreliable internal financial information } \\
\text { Failure to correct internal control weaknesses } \\
\text { Loss of records }\end{array}$ \\
\hline
\end{tabular}




\begin{tabular}{|c|c|}
\hline & Low internal control priority \\
\hline Heiman-Hoffman, Morgan \& Patton (1996) & Weak control environment \\
\hline IAASB (2004) & $\begin{array}{l}\text { Lack of proper control } \\
\text { Ineffective oversight over financial reporting process and internal } \\
\text { control }\end{array}$ \\
\hline Lee, Ingram \& Howard (1999) & Lack of proper management oversight \\
\hline $\begin{array}{l}\text { National Commission on Fraudulent Financial } \\
\text { Reporting (1987) }\end{array}$ & Weak control \\
\hline Powell \& Wilkinson (2002) & Lack of controls \\
\hline Rezaee (2002) & $\begin{array}{l}\text { Lack of or inadequate control structure } \\
\text { Poor corporate governance } \\
\text { Lack of internal audit function and structure }\end{array}$ \\
\hline Robertson (2002) & Weak internal control \\
\hline Schilit (1993) & Weak control environment \\
\hline \multicolumn{2}{|l|}{ 7. Culture } \\
\hline $\begin{array}{l}\text { Albrecht, Cherrington, Payne, Roe \& Romney } \\
\text { Elliot \& Willingham (1980) }\end{array}$ & $\begin{array}{l}\text { No rules regarding fraudsters } \\
\text { No uniform personnel policies } \\
\text { No code of ethics } \\
\text { Few interpersonal relationships } \\
\text { No dissatisfaction outlets }\end{array}$ \\
\hline Baucus \& Near (1991) & Certain company cultures \\
\hline Bell \& Carcello (2000) & Lack of ethics \\
\hline Du Plessis $(1999 b)$ & $\begin{array}{l}\text { Culture where results must be achieved at any cost } \\
\text { No code of ethics } \\
\text { Unquestioning staff obedience }\end{array}$ \\
\hline Ernst \& Young (2003) & $\begin{array}{l}\text { Low morale } \\
\text { Pressure to complete financial statements as soon as possible } \\
\text { Secrecy } \\
\text { No fraud policy }\end{array}$ \\
\hline $\begin{array}{l}\text { National Commission on Fraudulent Financial } \\
\text { Reporting (1987) }\end{array}$ & $\begin{array}{l}\text { Attitudes and actions of personnel and management } \\
\text { Existence and manner of code of conduct }\end{array}$ \\
\hline Rezaee (2002) & $\begin{array}{l}\text { Inappropriate or dishonest "tone at the top" } \\
\text { No code of conduct } \\
\text { No communication regarding values and ethical behaviour }\end{array}$ \\
\hline Robertson (2002) & Poor reputation \\
\hline hilit (1993) & Management have questionable character \\
\hline \multicolumn{2}{|l|}{ 8. Debt } \\
\hline $\begin{array}{l}\text { Albrecht, Cherrington, Payne, Roe \& Romney } \\
\text { in Elliot \& Willingham (1980) }\end{array}$ & $\begin{array}{l}\text { High debt } \\
\text { Reduced ability to get credit } \\
\text { Tough loan restrictions, little flexibility }\end{array}$ \\
\hline Apostolou, Hassell \& Webber (2001) & $\begin{array}{l}\text { High dependence on debt } \\
\text { Poor financial position }\end{array}$ \\
\hline Beneish (1997) & More leveraged growth-firms \\
\hline Dechow, Sloan \& Sweeney (1996) & More leveraged positions \\
\hline DeFond \& Jiambalvo (1991) & High leverage \\
\hline IAASB (2004) & Problems to meet debt repayments or covenant requirements \\
\hline Kinney \& McDaniel (1989) & Highly leveraged companies \\
\hline Lee, Ingram \& Howard (1999) & Highly leveraged firms \\
\hline Mitchell (1997) & High debt \\
\hline National Commission on Fraudulent Financial & High debt and problems to comply with debt covenants \\
\hline
\end{tabular}




\begin{tabular}{|c|c|}
\hline Reporting (1987) & \\
\hline Persons (1995) & Higher financial leverage \\
\hline Rezaee (2002) & $\begin{array}{l}\text { High debt } \\
\text { Closeness of debt covenant limits and high interest rates } \\
\text { Inability to obtain further credit }\end{array}$ \\
\hline \multicolumn{2}{|l|}{ 9. Directors } \\
\hline $\begin{array}{l}\text { Beasley (1996), } \\
\text { Beasley, Carcello \& Hermanson (2001), } \\
\text { Beasley, Carcello, Hermanson \& Lapides } \\
(2000)\end{array}$ & $\begin{array}{l}\text { Fewer outside directors on the board } \\
\text { Fewer outside directors on audit committee } \\
\text { Shorter tenures of outside directors } \\
\text { Larger boards } \\
\text { Weak board and audit committees } \\
\text { No audit committee } \\
\text { Founder also serving as CEO, chairman of the board }\end{array}$ \\
\hline Davia, Coggins, Wideman, Kastantin (2000) & A weak and inexperienced board of directors \\
\hline Dechow, Sloan \& Sweeney (1996) & $\begin{array}{l}\text { Mostly insiders on the board of directors } \\
\text { CEO is company founder and the board chairman } \\
\text { No audit committee }\end{array}$ \\
\hline Fond \& Jiambalvo (1991) & No audit committee \\
\hline Fridson \& Alvarez (2002) & $\begin{array}{l}\text { Lack of an audit committee } \\
\text { Poor audit committee }\end{array}$ \\
\hline Lee, Ingram \& Howard (1999) & More internal than external directors \\
\hline Mills (2003) & $\begin{array}{l}\text { CEO that controls board of directors } \\
\text { Not majority of independent outsiders (audit committee included) } \\
\text { Loans to directors } \\
\text { Not full-time membership on board of directors }\end{array}$ \\
\hline Mitchell (1997) & Frequent changes to board members \\
\hline $\begin{array}{l}\text { National Commission on Fraudulent Financial } \\
\text { Reporting (1987) }\end{array}$ & Absence of directors and/or audit committee \\
\hline Rezaee (2002) & $\begin{array}{l}\text { Mostly insiders on the board of directors } \\
\text { Short tenure of outside directors } \\
\text { Lack of corporate governance } \\
\text { Ineffective boards of directors } \\
\text { Not enough independent directors on the board } \\
\text { Audit committees (if any) not independent and ineffective }\end{array}$ \\
\hline Schilit (1993) & Too few independent members on the board of directors \\
\hline erman, Young \& Collingwood (2003) & Head of the audit committee not independent \\
\hline Van Wyk (2004) & One person both the chairman and CEO \\
\hline \multicolumn{2}{|l|}{ 10. Financial distress } \\
\hline Apostolou, Hassell \& Webber (2001) & Threat of bankruptcy \\
\hline Du Plessis (1999b) & Lack of financial stability \\
\hline Lee, Ingram \& Howard (1999) & Experiencing financial distress \\
\hline $\begin{array}{l}\text { National Commission on Fraudulent Financial } \\
\text { Reporting (1987) }\end{array}$ & Financial pressure \\
\hline Persons (1995) & Financial difficulty \\
\hline Robertson (2002) & Going-concern problems \\
\hline Saksena (2001) & Threat of insolvency \\
\hline Summers \& Sweeney (1998) & Poor financial conditions \\
\hline \multicolumn{2}{|l|}{ 11. Geographic location } \\
\hline $\begin{array}{l}\text { Albrecht, Cherrington, Payne, Roe \& Romney } \\
\text { in Elliot \& Willingham (1980) }\end{array}$ & Decentralised \\
\hline
\end{tabular}




\begin{tabular}{|c|c|}
\hline Bell \& Carcello (2000) & Decentralised \\
\hline Calderon \& Green (1994) & Decentralised \\
\hline Du Plessis (1999b) & Remote locations \\
\hline IAASB (2004) & $\begin{array}{l}\text { Significant operations located across international borders } \\
\text { Bank accounts or operations in tax-haven jurisdictions for which no } \\
\text { clear justification exists }\end{array}$ \\
\hline Price (1991) & Multinational companies are more difficult to control \\
\hline Robertson (2002) & $\begin{array}{l}\text { Decentralisation with remote locations } \\
\text { Tax haven operations }\end{array}$ \\
\hline \multicolumn{2}{|l|}{ 12. Growth } \\
\hline $\begin{array}{l}\text { Albrecht, Cherrington, Payne, Roe \& Romney } \\
\text { in Elliot \& Willingham (1980) }\end{array}$ & Rapid expansion \\
\hline Apostolou, Hassell \& Webber (2001) & Rapid growth \\
\hline Bell \& Carcello (2000) & $\begin{array}{l}\text { Rapid growth } \\
\text { Sales, mergers, purchases, acquisitions }\end{array}$ \\
\hline Beneish (1997) & Slower sales growth \\
\hline Calderon \& Green (1994) & Rapid growth \\
\hline zhow, Sloan \& Sweeney (1996) & Higher-growth opportunities \\
\hline DeFond \& Jiambalvo (1991) & Smaller growth in earnings \\
\hline Du Plessis (1999b) & Mismatch between growth and systems development \\
\hline Fridson \& Alvarez (2002) & Previous rapid growth now declining \\
\hline IAASB (2004) & Rapid growth, especially compared to others in the industry \\
\hline Kinney \& McDaniel (1989) & Slower growing companies \\
\hline Lee, Ingram \& Howard (1999) & $\begin{array}{l}\text { High growth } \\
\text { Larger sales growth }\end{array}$ \\
\hline Powell \& Wilkinson (2002) & Rapid growth \\
\hline Rezaee (2002) & $\begin{array}{l}\text { High earnings growth expectations } \\
\text { Unusually rapid growth } \\
\text { Rapid expansion }\end{array}$ \\
\hline Robertson (2002) & Rapid growth - leads to loss of control \\
\hline Schilit (1993) & $\begin{array}{l}\text { Fast growth beginning to slow } \\
\text { Very weak, trying to improve }\end{array}$ \\
\hline Sherman, Young \& Collingwood (2003) & $\begin{array}{l}\text { Falsely creating slower growth in a high-growth firm to refute negative } \\
\text { impact if results are expected to really falter later }\end{array}$ \\
\hline nmers \& Sweeney (1998) & $\begin{array}{l}\text { Rapid growth } \\
\text { It also happens that fraud is used to hide slower-growth rates }\end{array}$ \\
\hline \multicolumn{2}{|l|}{ 13. Industry } \\
\hline $\begin{array}{l}\text { Albrecht, Cherrington, Payne, Roe \& Romney } \\
\text { in Elliot \& Willingham }(1980)\end{array}$ & $\begin{array}{l}\text { Poor economic conditions in industry } \\
\text { Heavy competition }\end{array}$ \\
\hline Apostolou, Hassell \& Webber (2001) & $\begin{array}{l}\text { New accounting requirements in industry } \\
\text { High degree of competition } \\
\text { Declining industry } \\
\text { Rapid industry changes } \\
\text { Vulnerability to changing technology and product obsolescence }\end{array}$ \\
\hline Baucus \& Near (1991) & $\begin{array}{l}\text { History and structure of an industry } \\
\text { No enforcement agencies or regulatory bodies present } \\
\text { Inherent uncertainties } \\
\text { Dynamic environments } \\
\text { Specifically foods, lumber, petroleum refining and automobiles }\end{array}$ \\
\hline Beasley (1996), & Concentrations in healthcare, technology and financial services \\
\hline
\end{tabular}




\begin{tabular}{|c|c|}
\hline $\begin{array}{l}\text { Beasley, Carcello \& Hermanson (2001), } \\
\text { Beasley, Carcello, Hermanson \& Lapides } \\
(2000)\end{array}$ & \\
\hline Bell \& Carcello (2000) & $\begin{array}{l}\text { Sensitivity to economic factors } \\
\text { Rapid industry changes } \\
\text { Declining industry } \\
\text { Adverse conditions } \\
\end{array}$ \\
\hline Calderon \& Green (1994) & Industry decline \\
\hline Dechow, Sloan \& Sweeney (1996) & $\begin{array}{l}\text { Transport } \\
\text { Communication } \\
\text { Wholesale and retail } \\
\text { Manufacturing } \\
\text { Business services } \\
\end{array}$ \\
\hline Du Plessis (1999b) & Certain industry conditions \\
\hline Ernst \& Young (2003) & Results that are out of line with the rest of the industry \\
\hline Fridson \& Alvarez (2002) & New industry \\
\hline Hylas and Ashton (1982) & Some errors occur more frequently in certain companies \\
\hline IAASB (2004) & $\begin{array}{l}\text { High degree of competition } \\
\text { Vulnerability to change (e.g. technology, economy) } \\
\text { Decline in customer demand and increasing business failures } \\
\text { New accounting, statutory or regulatory requirements }\end{array}$ \\
\hline $\begin{array}{l}\text { National Commission on Fraudulent Financial } \\
\text { Reporting (1987) }\end{array}$ & $\begin{array}{l}\text { Impacting new accounting pronouncements } \\
\text { Seasonal fluctuations } \\
\text { High capital needs } \\
\text { Transition in industry environment }\end{array}$ \\
\hline Nieschwietz, Schultz Jr \& Zimbelman (2000) & Certain industries display more fraudulent behaviour \\
\hline Persons (1995) & $\begin{array}{l}\text { Computer and data processing, scientific and medical instrument } \\
\text { manufacturing, household appliances and electronic equipment } \\
\text { manufacturing and computer manufacturing }\end{array}$ \\
\hline Rezaee (2002) & $\begin{array}{l}\text { Some industry cultures increase fraud probability } \\
\text { Sudden industry decline } \\
\text { Highly competitive markets } \\
\text { Volatile industry } \\
\text { Technological changes } \\
\text { Aggressive or unrealistic forecasts of an industry }\end{array}$ \\
\hline bertson $(2002)$ & Oil, pharmaceutical and vehicle industries \\
\hline Saksena (2001) & $\begin{array}{l}\text { Dynamic, hostile industry } \\
\text { Heterogeneity between companies in the industry } \\
\text { Industry culture, structure and vulnerability to regulation }\end{array}$ \\
\hline Schilit (1993) & Strong competition \\
\hline Sherman, Young \& Collingwood (2003) & $\begin{array}{l}\text { Emerging markets and industries } \\
\text { Industries where legal and regulatory environment is weak }\end{array}$ \\
\hline \multicolumn{2}{|l|}{ 14. Liquidity } \\
\hline Du Plessis (1999b) & Poor liquidity \\
\hline $\begin{array}{l}\text { National Commission on Fraudulent Financial } \\
\text { Reporting (1987) }\end{array}$ & Poor liquidity \\
\hline Persons (1995) & Lower liquidity \\
\hline Rezaee (2002) & Lack of working capital \\
\hline Saksena (2001) & Lower liquidity \\
\hline
\end{tabular}




\begin{tabular}{|c|c|}
\hline $\begin{array}{l}\text { Albrecht, Cherrington, Payne, Roe \& Romney } \\
\text { in Elliot \& Willingham (1980) }\end{array}$ & $\begin{array}{l}\text { Weak leadership } \\
\text { Dishonest management } \\
\text { Dominant top management }\end{array}$ \\
\hline Apostolou, Hassell \& Webber (2001) & $\begin{array}{l}\text { High turnover of senior management } \\
\text { Pressure for aggressive accounting practices }\end{array}$ \\
\hline Bell \& Carcello (2000) & $\begin{array}{l}\text { Dominated by one person/small group } \\
\text { Aggressive attitude } \\
\text { High management turnover } \\
\text { Emphasis on earnings } \\
\text { Poor reputation } \\
\text { Inexperienced management } \\
\text { Undue risk-taking } \\
\end{array}$ \\
\hline Calderon \& Green (1994) & $\begin{array}{l}\text { Decisions dominated by one person or small group } \\
\text { High management turnover } \\
\text { Inexperienced } \\
\text { Conflict of interests } \\
\text { Undue emphasis on earnings } \\
\text { Dishonesty } \\
\text { Aggressive attitude towards financial reporting } \\
\text { Poor reputation } \\
\end{array}$ \\
\hline Du Plessis (1999b) & Autocratic management \\
\hline Ernst \& Young (2003) & Dominated by one person \\
\hline Heiman-Hoffman, Morgan \& Patton (1996) & $\begin{array}{l}\text { Dishonest management } \\
\text { Pressure to meet financial targets } \\
\text { Aggressive financial reporting } \\
\end{array}$ \\
\hline IAASB (2004) & $\begin{array}{l}\text { Management dominated by a single person or small group } \\
\text { Managers hold significant interests in the entity } \\
\text { Personal guarantees of entity debt } \\
\text { High turnover of managers }\end{array}$ \\
\hline Mills (2003) & $\begin{array}{l}\text { All information and ideas come from CEO } \\
\text { Transactions that lead to conflict of interests } \\
\text { Loans to senior executives }\end{array}$ \\
\hline Mitchell (1997) & High manager turnover \\
\hline $\begin{array}{l}\text { National Commission on Fraudulent Financial } \\
\text { Reporting (1987) }\end{array}$ & $\begin{array}{l}\text { A few managers dominate } \\
\text { Emphasis on meeting targets }\end{array}$ \\
\hline well \& Wilkinson (2002) & Poor communication between departments \\
\hline Rezaee (2002) & $\begin{array}{l}\text { Dominant management team with little/no accountability } \\
\text { Poor oversight of top managers } \\
\text { Not punishing fraudulent activity } \\
\text { Substantial discretion or judgement responsibility on management } \\
\text { Frequent turnover of management } \\
\text { Inexperienced management team } \\
\text { Autocratic management } \\
\text { Conflict of interests within management }\end{array}$ \\
\hline Robertson (2002) & $\begin{array}{l}\text { Decisions made by small group } \\
\text { Aggressive accounting attitude }\end{array}$ \\
\hline Schilit (1993) & Management team known/suspected of false behaviour \\
\hline Van Wyk (2004) & Excessive power by a few managers \\
\hline \multicolumn{2}{|l|}{ 16. Personnel } \\
\hline Albrecht, Cherrington, Payne, Roe \& Romney & Personnel living beyond their means \\
\hline
\end{tabular}




\begin{tabular}{|c|c|}
\hline in Elliot \& Willingham (1980) & $\begin{array}{l}\text { Perceived inequities } \\
\text { Rapid personnel turnover } \\
\text { No annual vacations } \\
\text { No rotations or transfers of key personnel } \\
\text { No proper screening of potential employees } \\
\text { Too much trust in key personnel } \\
\text { Inexperienced personnel in key positions }\end{array}$ \\
\hline Apostolou, Hassell \& Webber (2001) & Aggressive incentive programmes \\
\hline Bell \& Carcello (2000) & $\begin{array}{l}\text { Inexperienced accounting personnel } \\
\text { Lavish lifestyles personnel should not be able to afford }\end{array}$ \\
\hline Du Plessis (1999b) & $\begin{array}{l}\text { Mismatches of personality and status } \\
\text { Unusual behaviour } \\
\text { Expensive lifestyles } \\
\text { Untaken holidays } \\
\text { Poorly trained staff } \\
\text { Poor quality staff } \\
\text { Low morale } \\
\text { Regular overtime } \\
\text { High staff turnover } \\
\end{array}$ \\
\hline Ernst \& Young (2003) & $\begin{array}{l}\text { High turnover of key accounting and financial personnel } \\
\text { Understaffing of departments } \\
\text { No enforced holidays } \\
\text { Too lavish lifestyles } \\
\text { Excessive hours worked by key staff } \\
\text { No checking of employees' references } \\
\end{array}$ \\
\hline IAASB (2004) & $\begin{array}{l}\text { High turnover of employees } \\
\text { Ineffective staff for accounting, internal control and IT }\end{array}$ \\
\hline $\begin{array}{l}\text { National Commission on Fraudulent Financial } \\
\text { Reporting (1987) }\end{array}$ & $\begin{array}{l}\text { High turnover in key personnel } \\
\text { Instability in the lives of personnel } \\
\text { Feelings of dissatisfaction }\end{array}$ \\
\hline Powell \& Wilkinson (2002) & $\begin{array}{l}\text { High personnel turnover } \\
\text { No-one taking responsibility for the accounting function }\end{array}$ \\
\hline Robertson (2002) & $\begin{array}{l}\text { Unexplained lifestyle changes } \\
\text { Inexperienced staff } \\
\text { Difficult and lax personnel }\end{array}$ \\
\hline \multicolumn{2}{|l|}{ Profitability } \\
\hline $\begin{array}{l}\text { Albrecht, Cherrington, Payne, Roe \& Romney } \\
\text { in Elliot \& Willingham (1980) }\end{array}$ & Expenses rising faster than revenues \\
\hline Apostolou, Hassell \& Webber (2001) & High profitability relative to industry \\
\hline Baucus \& Near (1991) & Moderate to good performance \\
\hline $\begin{array}{l}\text { Beasley (1996), } \\
\text { Beasley, Carcello \& Hermanson (2001), } \\
\text { Beasley, Carcello, Hermanson \& Lapides } \\
(2000)\end{array}$ & Often in a net loss or break-even situation \\
\hline Bell \& Carcello (2000) & Inconsistent profitability \\
\hline Beneish (1997) & Deteriorating gross margins \\
\hline Calderon \& Green (1994) & Inadequate compared to industry \\
\hline Dechow, Sloan \& Sweeney (1996) & Heavy reliance on earnings performance \\
\hline DeFond \& Jiambalvo (1991) & Lower earnings \\
\hline Du Plessis (1999b) & Not meeting expectations \\
\hline
\end{tabular}




\begin{tabular}{|c|c|}
\hline & Profit in excess of industry norms \\
\hline Ernst \& Young (2003) & $\begin{array}{l}\text { High levels of profits or losses } \\
\text { Profits and cash flows at variance with each other } \\
\text { Deteriorating quality of earnings } \\
\text { Needs rising profit trend to support share market price }\end{array}$ \\
\hline IAASB (2004) & Unusual profitability, especially compared to others in the industry \\
\hline Kinney \& McDaniel (1989) & Less profitable \\
\hline Lee, Ingram \& Howard (1999) & Higher earnings \\
\hline $\begin{array}{l}\text { National Commission on Fraudulent Financial } \\
\text { Reporting (1987) }\end{array}$ & Sudden decreases \\
\hline Persons (1995) & Lower profitability \\
\hline Powell \& Wilkinson (2002) & $\begin{array}{l}\text { Poor return on capital employed } \\
\text { Inconsistent profit and revenue trends }\end{array}$ \\
\hline Rezaee (2002) & Decline in the quality and quantity of earnings \\
\hline Robertson (2002) & Emphasis on earnings \\
\hline Saksena (2001) & Poor financial performance \\
\hline Shilit (1993) & $\begin{array}{l}\text { Sudden high profitability } \\
\text { Sudden low profitability }\end{array}$ \\
\hline Sherman, Young \& Collingwood (2003) & Working towards specific earnings targets \\
\hline Summers \& Sweeney (1998) & High profitability \\
\hline \multicolumn{2}{|l|}{ 18. Receivables and inventories } \\
\hline Beneish (1997) & Decline in inventory and receivable turnovers \\
\hline Fridson \& Alvarez (2002) & Increased receivables \\
\hline Lee, Ingram \& Howard (1999) & Larger amounts of receivables and inventories \\
\hline Nieschwietz, Schultz Jr \& Zimbelman (2000) & Asset overstatement \\
\hline Persons (1995) & Overstatement of receivables and inventories \\
\hline Rezaee (2002) & $\begin{array}{l}\text { Excessive bad debt resulting from inability to collect receivables } \\
\text { High inventory values, indicating overstatement } \\
\text { Inventories stored in unusual locations or manners } \\
\text { Special expertise needed to value inventory } \\
\text { Increase in inventory without increase in sales }\end{array}$ \\
\hline Schilit (1993) & $\begin{array}{l}\text { Large amounts of overdue receivables } \\
\text { Related-party receivables } \\
\text { Slow receivables and/or receivables turnover } \\
\text { Large growth of inventory without growth in sales }\end{array}$ \\
\hline mmers \& Sweeney (1998) & High inventory relative to sales \\
\hline \multicolumn{2}{|l|}{ 19. Remuneration } \\
\hline Bell \& Carcello (2000) & Remuneration based on performance \\
\hline Calderon \& Green (1994) & Remuneration based on recorded performance \\
\hline Dechow, Sloan \& Sweeney (1996) & Remuneration based on earnings \\
\hline Du Plessis (1999b) & Compensation tied to performance \\
\hline Ernst \& Young (2003) & Remuneration based on financial performance \\
\hline IAASB (2004) & $\begin{array}{l}\text { Significant compensation portions contingent on aggressive financial } \\
\text { targets }\end{array}$ \\
\hline Rezaee (2002) & Compensation for executives linked to earnings or stock price targets \\
\hline Robertson (2002) & Remuneration based on performance \\
\hline $\begin{array}{l}\text { National Commission on Fraudulent Financial } \\
\text { Reporting (1987) }\end{array}$ & Remuneration based on economic performance \\
\hline Sherman, Young \& Collingwood (2003) & Compensation linked to short-term financial business goals \\
\hline
\end{tabular}




\begin{tabular}{|c|c|}
\hline \multicolumn{2}{|l|}{ 20. Shareholding } \\
\hline $\begin{array}{l}\text { Beasley (1996), } \\
\text { Beasley, Carcello \& Hermanson (2001), } \\
\text { Beasley, Carcello, Hermanson \& Lapides } \\
(2000)\end{array}$ & $\begin{array}{l}\text { Lower outside ownership in the company } \\
\text { Insiders own significant portions } \\
\text { Less likely to have a block-holder as shareholder }\end{array}$ \\
\hline Bell \& Carcello (2000) & Management holds a significant portion of company's shares \\
\hline Beneish (1997) & Large number of shares held by management \\
\hline Calderon \& Green (1994) & Represent a significant portion of management's own wealth \\
\hline Lee, Ingram \& Howard (1999) & More equity securities issued \\
\hline Nieschwietz, Schultz Jr \& Zimbelman (2000) & Publicly owned companies \\
\hline Rezaee (2002) & $\begin{array}{l}\text { High level of share ownership by management } \\
\text { Low stockholding by outside directors (no incentive for them to exert } \\
\text { stronger control) }\end{array}$ \\
\hline \multicolumn{2}{|l|}{ 21. Stock market performance } \\
\hline $\begin{array}{l}\text { Albrecht, Cherrington, Payne, Roe \& Romney } \\
\text { in Elliot \& Willingham (1980) }\end{array}$ & Suspension or delisting \\
\hline Beneish (1997) & Poor stock market performance \\
\hline Lechow, Sloan \& Sweeney (1996) & \begin{tabular}{|l|} 
Poor performance \\
Higher market-to-book ratios
\end{tabular} \\
\hline Du Plessis (1999b) & Not meeting expectations \\
\hline Lee, Ingram \& Howard (1999) & \begin{tabular}{|l|} 
Poor stock market performance \\
Larger market values relative to assets \\
\end{tabular} \\
\hline $\begin{array}{l}\text { National Commission on Fraudulent Financial } \\
\text { Reporting (1987) }\end{array}$ & Sudden decreases \\
\hline Rezaee (2002) & $\begin{array}{l}\text { Recently started trading publicly } \\
\text { High prices (need more earnings to support it) } \\
\text { Suspension or delisting from stock exchange }\end{array}$ \\
\hline \multicolumn{2}{|l|}{ 22. Structure } \\
\hline $\begin{array}{l}\text { Albrecht, Cherrington, Payne, Roe \& Romney } \\
\text { in Elliot \& Willingham (1980) }\end{array}$ & Complex structure \\
\hline Apostolou, Hassell \& Webber (2001) & Complex structures \\
\hline Du Plessis (1999b) & Complex structures \\
\hline Ernst \& Young (2003) & Complex corporate structure \\
\hline IAASB (2004) & Complex structure \\
\hline inney \& McDaniel (1989) & Changes in business conditions and structure \\
\hline Lendez \& Korevec (1999) & Complex structures \\
\hline Mitchell (1997) & Complex business structure \\
\hline $\begin{array}{l}\text { National Commission on Fraudulent Financial } \\
\text { Reporting (1987) }\end{array}$ & $\begin{array}{l}\text { Complex structure } \\
\text { Structure changes }\end{array}$ \\
\hline Rezaee (2002) & $\begin{array}{l}\text { Complex structure } \\
\text { Frequent changes }\end{array}$ \\
\hline Robertson (2002) & Complex structure \\
\hline Sherman, Young \& Collingwood (2003) & Complex ownership and financial structures \\
\hline Van Wyk (2004) & Inadequate corporate governance structures \\
\hline
\end{tabular}

Of the 22 characteristics and behaviours that were observed, 18 showed a definitive trend that can be an indication of irregularities. Table 3 presents the four characteristics out of the 22 for which no clear conclusion was reached. 
Table 3: Characteristics with unclear results or inconsistencies.

\begin{tabular}{|l|l|l|}
\hline Nr. & \multicolumn{1}{|c|}{ Characteristic category } & Result \\
\hline 5. & Company size & $\begin{array}{l}\text { Inconclusive outcome due to varying views whether companies with } \\
\text { fraudulent activity tended to be older or younger. }\end{array}$ \\
\hline 12. & Growth & $\begin{array}{l}\text { Inconclusive outcome. Slow growth gives an incentive to improve } \\
\text { results through unethical means. On the other hand, fast growth has to } \\
\text { be maintained, often through fraudulent means. }\end{array}$ \\
\hline 17. & Profitability & $\begin{array}{l}\text { Inconclusive outcome. Poor profitability gives an incentive to } \\
\text { improve by unethical means while good profitability has to be } \\
\text { maintained indefinitely. }\end{array}$ \\
\hline 21. & Stock market performance & $\begin{array}{l}\text { Inconclusive outcome. Poor performance gives an incentive to } \\
\text { improve by unethical means while good performance has to be } \\
\text { maintained. }\end{array}$ \\
\hline
\end{tabular}

Table 4 is a summary of the 18 remaining characteristics that may be indicative of irregularities together with the specific behaviour that is most often displayed in cases of unethical and/or fraudulent actions.

Table 4: Characteristics and behaviours often associated with companies that engage in fraudulent activities

\begin{tabular}{|l|l|l|}
\hline Nr. & Characteristic category & \multicolumn{1}{c|}{ Result } \\
\hline 1. & Accounting transactions & $\begin{array}{l}\text { Accounting practices and transactions tend to be complex. } \\
\text { Subjective judgements are often used. } \\
\text { Significant related-party transactions. }\end{array}$ \\
\hline 2. & Auditors & $\begin{array}{l}\text { Frequent changes of auditors. } \\
\text { Strained relationship between management and auditors. } \\
\text { Attempts to influence auditors. } \\
\text { Disputes with auditors. } \\
\text { Withholding information from auditors. }\end{array}$ \\
\hline 3. & Cash flow & Poor cash flow, especially in relation to profit. \\
\hline 4. & Company age & Companies are more often younger. \\
\hline 6. & Control & A poor/weak control environment. \\
\hline 7. & Culture & $\begin{array}{l}\text { A lack of documentation to formalise processes (e.g. code } \\
\text { of conduct, ethics policy, fraud policy) }\end{array}$ \\
\hline 8. & Debt & Tendency to have higher debt. \\
\hline 9. & Directors & $\begin{array}{l}\text { Few outsiders on the board of directors. } \\
\text { A weak, or in some cases, no audit committee. }\end{array}$ \\
\hline 10. & Financial distress & $\begin{array}{l}\text { The presence of high financial pressure can often be } \\
\text { observed. }\end{array}$ \\
\hline 11. & Geographic location & \begin{tabular}{l} 
Decentralised companies have higher risk. \\
\hline
\end{tabular}
\end{tabular}




\begin{tabular}{|c|c|c|}
\hline 13. & Industry & $\begin{array}{l}\text { Volatile industries where changes (e.g. technology) are } \\
\text { frequent and significant. } \\
\text { A high level of competition. } \\
\text { Certain economic factors affect certain industries. } \\
\text { Inconclusive results were obtained with regard to specific } \\
\text { industries. }\end{array}$ \\
\hline 14. & Liquidity & Risky companies often have poor liquidity. \\
\hline 15. & Management & $\begin{array}{l}\text { Autocratic or dominant management team makes unethical } \\
\text { behaviour by management easier. } \\
\text { A high management turnover is often present. } \\
\text { Conflict of interests. } \\
\text { An emphasis on shorter-term performance. }\end{array}$ \\
\hline 16. & Personnel & $\begin{array}{l}\text { Rapid turnover of personnel. } \\
\text { Lavish lifestyles of personnel, especially management. }\end{array}$ \\
\hline 18. & Receivables and inventory & Increases in receivables and/or inventory. \\
\hline 19. & Remuneration & Based on shorter-term performance. \\
\hline 20. & Shareholding & $\begin{array}{l}\text { High levels of internal shareholding (by management } \\
\text { and/or directors). }\end{array}$ \\
\hline 22. & Structure & Companies with complex structures are more at risk. \\
\hline
\end{tabular}

Parties that have an interest in a company can use these characteristics to make an assessment of the company's accounting and/or financial statement fraud risk.

\section{CONCLUSION}

From an analysis of the research results of a number of book and journal authors, 22 behavioural characteristics were identified as being present when companies have a greater accounting risk and perhaps a greater likelihood to engage in financial statement fraud. From these 22 characteristics, four were eliminated as a result of showing inconclusive results while the remaining 18 characteristics were identified as similar to behaviour in companies that engage in financial statement fraud. These characteristics can be used as a model by any party with an interest in a company to assess the company's likelihood of engaging in unethical and perhaps fraudulent activities. These characteristics can also be used to create a profile for companies with a higher risk of defrauding investors and the public.

The results of the study also provide proof that it is not enough to analyse only the quantitative information on a company in order to determine its accounting risk and/or propensity for 
financial statement fraud actions. Qualitative information may also have significant predictive power. This predictive power arises from cultural and other qualitative characteristics that tend to be the norm in companies with a higher accounting and/or financial statement fraud risk.

It is important to note that the 18 behavioural characteristics that were positively identified as fraud risk indicators in the previous section do not necessarily provide definitive proof of unethical behaviour, accounting risk and/or fraudulent activity. Many of the actions that are taken by managers may be totally within the law, but can be used to fulfil the same purpose as financial statement fraud. However, such accounting practices heighten accounting risk and have the potential to develop into fraud and are thus worth detecting in advance.

If the indicators are to be used by outside parties alone (therefore excluding parties with internal information like managers and auditors), the list of 18 characteristics may have to be shortened even more, as some of the characteristics may not be analysable due to a lack of information. One example is the control environment. The information related to the internal functions of a company is not readily available to outsiders. Relationships with auditors and information about the lifestyles of personnel are also not available. Apart from information that is not available, some of the characteristics about which information can be easily obtained are difficult to analyse. One such category is the industry in which a company operates. The criteria for determining which factors indicate a volatile industry are not formally defined.

However, with or without further sifting, some of the characteristics can be applied successfully in assessing the accounting risk a company faces, as well as the possibility of financial statement fraud.

\section{FURTHER RESEARCH}

There is still room for further analysis of the characteristics that companies display in order to determine if there is truth in the concept of indicators of possible financial statement fraud. The author is currently busy with further analysis into the characteristics and behavioural aspects of 
companies that engage(d) in financial statement fraud. The results from the study will possibly be presented in a follow-up article.

\section{REFERENCES}

Altman, E.I. \& Hotchkiss, E. 2006. Corporate financial distress and bankruptcy. $3^{\text {rd }}$ Edition. New Jersey: John Wiley.

Apostolou, B., Hassell, J.M. \& Webber, S.A. 2001. Management fraud risk factors: ratings by forensic experts. The CPA Journal. 71(10):48-52.

Baucus, M.S. \& Near, J.P. 1991. Can illegal corporate behaviour be predicted? An event history analysis. Academy of Management Journal. 34(1):9-36.

Beasley, M.S. 1996. An empirical analysis of the relation between the board of director composition and financial statement fraud. The Accounting Review. 71(4):443-465.

Beasley, M.S., Carcello, J.V. \& Hermanson, D.R. 2001. Financial reporting fraud: could it happen to you? The Journal of Corporate Accounting \& Finance. 12(4):3-9.

Beasley, M.S., Carcello, J.V., Hermanson, D.R. \& Lapides, P.D. 2000. Fraudulent financial reporting: consideration of industry traits and corporate governance measures. Accounting Horizons. 14(4):441-454.

Bell, T.B. \& Carcello, J.V. 2000. A decision aid for assessing the likelihood of fraudulent financial reporting. Auditing. 19(1):169-184.

Beneish, M.D. 1997. Detecting GAAP violation: implications for assessing earnings management among firms with extreme financial performance. Journal of Accounting and Public Policy. 16:271-309.

Calderon, T.G. \& Green, B.P. 1994. Signalling fraud by using analytical procedures. Ohio CPA Journal. 53(2):27-38.

Cameron-Ellis, R. 2000. Fraud: corporate governance fraud prevention. Black Business Quarterly. 2(2):66-67.

Christophers, H. 2005. A higher profile for corporate fraud. Business Brief. 10(5):27-28. 
Connelley, M. 2003. Chapter 5: scams, schemes and scoundrels. Auditing for internal fraud. p. 5-19. New York. AICPA.

Cressey, D.R. 1986. Why managers commit fraud. Australian and New Zealand Journal of Criminology. 19(4):195-209.

Daroca, F.P. \& Holder, W.W. 1985. The use of analytical procedures in review and audit engagements. Auditing: A Journal of Practice \& Theory. 4(2):80-92.

Davia, H.R., Coggins, P.C., Wideman, J.C. \& Kastantin, J.T. 2000. Accountant's guide to fraud detection and control. 2nd Edition. New York: John Wiley.

Dawson, S. 2001. Fraud: defusing the corporate bomb. Executive Business Brief. 6(5):14-15.

Dechow, P.M., Sloan, R.G. \& Sweeney, A.P. 1996. Causes and consequences of earnings manipulations: an analysis of firms subject to enforcement actions by the SEC. Contemporary Accounting Research. 13(1):1-36.

DeFond, M.L. \& Jiambalvo, J. 1991. Incidence and circumstances of accounting errors. The Accounting Review. 66(3):643-655.

Du Plessis, D.E. 1997. Aspects of forensic accounting and auditing. Accountancy and Finance Update. April:11-13.

Du Plessis, D.E. 1999a. Fraudulent financial statements. Accountancy and Finance Update, $4(5): 2-5$.

Du Plessis, D.E. 1999b. Leeson and Barings Bank: a case study on security fraud risks. Accountancy and Finance Update. April:25-28.

Du Plessis, D.E. 2001. A growing concern. Accountancy SA. July:4-6.

Du Plessis, D.E. \& Koornhof, C. 2000. Red flagging as an indicator of financial statement fraud: the perspective of investors and lenders. Meditari Accountancy Research. 8:69-93.

Elliot, R.K. \& Willingham, J.J. 1980. Management fraud: detection and deterrence. New York: Petrocelli Books.

Ernst \& Young South Africa. 2003. Fraud risk and prevention. http://www.sacob.co.za. Accessed April 2003. 
Fridson, M. \& Alvarez, F. 2002. Financial statement analysis: a practitioner's guide. $3^{\text {rd }}$ Edition. New York: John Wiley.

Gerety, M. \& Lehn, K. 1997. The causes and consequences of accounting fraud. Managerial and Decision Economics (1986-1998). 18(7/8):587-599.

Glover, H.D. \& Aono, J.Y. 1995. Changing the model for prevention and detection of fraud. Managerial Auditing Journal. 10(5):3-9.

Heiman-Hoffman, V.B., Morgan, K.P. \& Patton, J.M. 1996. The warning signs of fraudulent financial reporting. Journal of Accountancy. 182(4):75-76.

Holder, W.W. 1983. Analytical review procedures in planning the audit: an application study. Auditing: A Journal of Practice and Theory. 2(2):100-107.

Hylas, R.E. \& Ashton, R.H. 1982. Audit detection of financial statement errors. The Accounting Review. 57(4):751-765.

Institute of Internal Auditors (IIA). 2001. Practice Advisory 1210.A2-1: Identification of fraud. http://www.theiia.org/iia/.

International Auditing and Assurance Standards Board (IAASB). 2007. Objective and general principles governing an audit of financial statements (ISA 200). http:/www.ifac.org/Members/DownLoads/2007_IAASB_Handbook.pdf. （Accessed 20 August 2007)

International Auditing and Assurance Standards Board (IAASB). 2007. The auditor's responsibility to consider fraud in an audit of financial statements (ISA 240). http://www.ifac.org/Members/DownLoads/2007_IAASB_Handbook.pdf (Accessed 20 August 2007)

Kaminski, K.A., Wetzel, T.S. \& Guan L. 2004. Can financial ratios detect fraudulent financial reporting? Managerial Auditing Journal. 19(1):15-28.

Kinney, W.R. 1979. The predictive power of limited information in preliminary analytical review: an empirical study. Journal of Accounting Research. 17(Supplement):148-165. 
Kinney, W.R. \& McDaniel, L.S. 1989. Characteristics of firms correcting previously reported quarterly earnings. Journal of Accounting and Economics. February:71-94.

Krambia-Kapardis, M. 2002. A fraud detection model: a must for auditors. Journal of Financial Regulation and Compliance. 10(3):266-278.

Lee, T.A., Ingram, R.W. \& Howard, T.P. 1999. The difference between earnings and operating cash flow as an indicator of financial reporting fraud. Contemporary Accounting Research. 16(4):749-786.

Lendez, A.M. \& Korevec, J.J. 1999. How to prevent and detect financial statement fraud. The Journal of Corporate Accounting \& Finance. 11(1):47-54.

Mills, D.Q. 2003. Wheel, deal and steal: deceptive accounting, deceitful CEOs and ineffective reforms. New Jersey: Prentice-Hall.

Minnaar-Van Veijeren, J. 2000a. Origin and characteristics of white collar crime. Management Today. 16(8):37.

Minnaar-Van Veijeren, J. 2000b. The elements of fraud. Management Today. 16(7):49-50.

Minnaar-Van Veijeren, J. 2000c. The origin and definition of fraud. Management Today. $16(6): 38$.

Mitchell, S.H. 1997. Management fraud trends. The Secured Lender New York. 53(6):104-108.

Moyes, G.D. \& Hasan, I. 1996. An empirical analysis of fraud detection likelihood. Managerial Auditing Journal. 11(3):41.

National Commission on Fraudulent Financial Reporting. 1987. Report of the National Commission on Fraudulent Financial Reporting. http://www.coso.org/publications.htm.

Nieschwietz, R.J., Schultz Jr, J.J. \& Zimbelman, M.F. 2000. Empirical research on external auditors' detection of financial statement fraud. Journal of Accounting Literature. 19:190246.

Padgett, S. 2004. Current fraud trends. Government and Corporate Fraud Conference. Indaba Hotel, Fourways, Johannesburg, AMC International. 21-23 April 2004. 
Persons, O.S. 1995. Using financial statement data to identify factors associated with fraudulent financial reporting. Journal of Applied Business Research. 11(3):38-47.

Perumaul, I. 2004. A structured approach to forensic auditing. Government and Corporate fraud Conference. Indaba Hotel, Fourways, Johannesburg, AMC International. 21-23 April 2004.

Powell, R. \& Wilkinson, J. 2002. Accounts manipulation. The Fraud Magazine of KPMG Forensic. July:2.

Price, D. 1991. Fraudbusting. London: Mercury.

Rezaee, Z. 2002. Financial statement fraud: prevention and detection. New York: John Wiley.

Robertson, J.C. 2002. Fraud examination for managers and auditors. $4^{\text {th }}$ Edition. Austin, Texas: Viesca.

Rosplock, M. 2001. Advanced forensic analysis: part two. The White Paper. 15(6) Nov/Dec:2325.

Saksena, P. 2001. The relationship between environmental factors and management fraud: an empirical analysis. International Journal of Commerce \& Management: Indiana. 11(1):120139.

Savage, M. 2003. Food for insomnia. Accountancy SA. May:6-7.

Schilit, H.M. 1993. Financial shenanigans: how to detect accounting gimmicks and fraud in financial reports. New York: McGraw-Hill.

Sherman, H.D., Young, S.D. \& Collingwood, H. 2003. Profits you can trust: spotting and surviving accounting landmines. New Jersey: Pearson.

South Africa. 2005. Auditing Profession Act, Act 26 of 2005. Pretoria: Government Printer.

South African Police Service: Crime information analysis centre. 2005. Commercial Crime in the RSA for the period April to March 2001/2002 to 2004/2005. http://www.saps.gov.za/statistics/reports/crimestats/2005/_pdf/crimes/commercial_crime.pdf. Accessed 7 November 2005.

Summers, S.L. \& Sweeney, J.T. 1998. Fraudulently misstated financial statements and insider trading: an empirical analysis. The Accounting Review. 73(1):131-146. 
Tipgos, M.A. 2002. Why management fraud is unstoppable. The CPA Journal. 72(12):34-41.

Vaksman, V. 2004. Achieve compliance and better business. Accountancy SA. Nov/Dec:19.

Van Wyk, M. 2004. Fraudulent financial reporting, power and financial governance: corporate governance. Accountancy SA. Jan:2-4.

Wells, J.T. 1990. Six common myths about fraud. Journal of Accountancy. 169(2):82-88.

Wells, J.T. 1997. Occupational fraud and abuse. Austin, Texas: Obsidian.

Wells, J.T. 2001. ...And nothing but the truth: uncovering fraudulent disclosures. Journal of Accountancy. 192(1):47-52. 